https://doi.org/10.15407/ujpe65.8.670

N.YE. MITINA, ${ }^{1}$ A.O. RIABTSEVA, ${ }^{1,2}$ V.M. GARAMUS,${ }^{3}$ R.B. LESYK,${ }^{4}$

K.A. VOLYANYUK, ${ }^{1}$ O.M. IZHYK, ${ }^{1}$ O.S. ZAICHENKO ${ }^{1}$

${ }^{1}$ Lviv Polytechnic National University

(12, S. Bandery Str., Lviv 79013, Ukraine; emails: nmitina10@gmail.com, k.volianiuk@gmail.com,izhykoleh18@gmail.com,zaichenk@polynet.lviv.ua)

${ }^{2}$ Queen's University

(99, University Ave., Kingston, ON KYL 3N6, Canada; e-mail: a.riabtseva@gmail.com)

${ }^{3}$ Helmholtz-Zentrum Geesthacht: Centre for Materials and Coastal Research (HZG)

(Max-Planck-Str. 1, 21502 Geesthacht, Germany; e-mail: vasyl.haramus@hzg.de)

${ }^{4}$ Danylo Halytsky Lviv National Medical University

(69a, Pekarska Str., Lviv 79010, Ukraine; e-mail: roman.lesyk@gmail.com)

\title{
MORPHOLOGY OF THE MICELLES \\ FORMED BY A COMB-LIKE PEG-CONTAINING COPOLYMER LOADED WITH ANTITUMOR SUBSTANCES WITH DIFFERENT WATER SOLUBILITIES
}

\begin{abstract}
The controlled delivery of anticancer drugs is driven by their interaction with carrier molecules. By creating complicated micelle-like complexes, amphiphilic polymers provide an opportunity to load drugs of various kinds. In this work, the interaction of the comb-like PEGcontaining polymer poly(VEP-co-GMA)-graft-PEG with the water-soluble antitumor antibiotic doxorubicin and new water-insoluble derivatives of thiozalidinone Les-3883 characterized by a high anticancer efficiency has been studied in aqueous solutions by means of the SAXS, DLS, TEM, and photoluminescence methods. The formation of polymer micelles and their complexes with drugs, as well as their structural changes, is observed. The obtained results give evidence that the mechanism of organization of supramolecular complexes depends on the drug solubility in water. A potential capability of poly(VEP-co-GMA)-graft-PEG to prolong the drug circulation lifetime is confirmed.
\end{abstract}

Keywords: small-angle X-ray scattering, micelle morphology, hydrophobic/hydrophilic drugs, polymer-drug complexes.

\section{Introduction}

Nowadays, chemotherapy is the main method to treat various tumors [1]. However, multidrug resistance is one of the obstacles to cancer chemotherapy. To reach a required therapeutic dose of drugs in the body, it is necessary to increase the drug concentration [2]. The application of micellar carriers consisting of amphiphilic polymer molecules to deliver drugs with high total toxicity allows the therapeutic drug dose to be reduced by an order of magnitude keeping a high therapeutic efficiency.

The development of new surfactant polymers that form micelle-like supramolecular structures is a

(C) N.YE. MITINA, A.O. RIABTSEVA, V.M. GARAMUS, R.B. LESYK, K.A. VOLYANYUK, O.M. IZHYK,

O.S. ZAICHENKO, 2020 promising way for the creation of stable aqueous systems aimed at the controlled delivery of drugs and nucleic acids, in particular, in chemotherapy and genetic engineering. The architecture, functionality, and molecular-weight characteristics of surfactant polymers are known [3-5] to be responsible for the colloidchemical characteristics - namely, the size, charge, morphology, and stability - of the micelles and vesicles, as well as intermolecular complexes and particles, formed by them in solutions, and for their ability to immobilize and to solubilize physiologically active substances in such containers-carriers.

Polymers containing polyethylene glycol (PEG) attract the enhanced attention in biomedical studies owing to their high biocompatibility and a wide range of controllable physicochemical properties [6]. Furthermore, the introduction of various functional frag-

ISSN 2071-0194. Ukr. J. Phys. 2020. Vol. 65, No. 8 
ments into the composition of such copolymers - e.g., using the copolymerization method or by grafting hydrophobic/hydrophilic polymer chains - allows their properties to be varied in a wide interval $[7,8]$. Polymer micelles produced from the molecules of such surfactant polymers are promising containers to deliver drugs, in particular, anticancer ones [9]. They protect those drugs from damages and the uncontrolled release during their transport in the body, provide their prolonged circulation in the circulatory system, and enhance the drug effect as a result of the cell sensibilization [10]. A substantial advantage of PEG-containing comb-like polymers is a possibility to control the size and morphology of the formed micelles, as well as the content of biologically active substances, by varying the lengths of the main and lateral PEG chains [11].

Water-soluble doxorubicin hydrochloride, which was used in this work, is one of the most popular anticancer drugs in the clinical practice [12]. At the same time, Les-3833, a water-insoluble synthetic derivative of 4-thiozalidinone, is widely studied now as an effective drug for the treatment of glioblastoma [13].

Micelles of comb-like PEG-containing polymers revealed themselves as effective universal carriers of drugs $[7,14]$. They reliably bind various hydrophilic and hydrophobic antitumor drugs, protect them against biological damages, provide their targeted delivery and high therapeutic efficiency. Both in vitro and in vivo studies [15] showed that comb-like PEGcontaining polymer carriers have a high biological tolerance. At the same time, the mechanisms giving rise to the formation of complexes including such carriers and drugs of various nature, and, as a result, the morphology of the formed nanoscale complexes have not been studied enough.

In modern structural studies of various supramolecular structures - micelles, vesicles, and nanoparticles - such methods as small-angle X-ray scattering (SAXS) and small-angle neutron scattering (SANS) are actively applied [16-19]. This fact made it expedient to carry out in-depth studies of the colloid-chemical characteristics and the morphology of polymer micelles formed by poly(VEP-co-GMA)graft-PEG (Fig. 1), as well as their complexes with hydrophilic and hydrophobic anticancer substances, making use of the SAXS, dynamic light scattering (DLS), transmission electron microscopy (TEM), and photoluminescence methods.

ISSN 2071-0194. Ukr. J. Phys. 2020. Vol. 65, No. 8

\section{Experimental Part}

\subsection{Materials}

Polyethylene glycol monomethyl ether (mPEG, $M_{n}=$ $=750 \mathrm{Da})$, dimethyl sulfoxide (DMSO), azobisisobutyronitrile (AIBN), and boron trifluoride ethyl ether were obtained from Sigma-Aldrich and used without additional purification. The glycidyl methacrylate monomer (GMA, Merck, Germany) was purified by the distillation in vacuum. Peroxide monomer 5-tert-butyl-peroxy-5-methyl-1-hexene-3-yne (VEP) was synthesized following the known method [20]. Doxorubicin (Dox) was purchased from Arterium Corporation (Ukraine). Waterinsoluble drug Les-3833, a heterocyclic derivative of 4-thiozalidinone, was synthesized at the Department of Pharmaceutical, Organic, and Bioorganic Chemistry of the Danylo Danylo Halytsky Lviv National Medical University following the procedure described earlier [21].

The comb-like copolymer poly(VEP-co-GMA)graft-mPEG with the structure shown in Fig. 1 was synthesized at the Department of Organic Chemistry of the Lviv Polytechnic National University according to the method described in work [7]. At the first stage, with the help of the AIBN-initiated radical copolymerization, the epoxy-containing copolymer poly(VEP-co-GMA) was produced. At the second stage, this copolymer was used as a precursor to synthesize the PEG-containing polymer. For this purpose, the solution of poly(VEP-co-GMA) was added to a solution of $\mathrm{mPEG}$ in the presence boron trifluoride ethyl etherate as an addition-reaction catalyst. The composition of the synthesized copolymer was determined using the methods of elemental analysis and analysis of functional groups [22, 23]. The composition of the obtained copolymer was confirmed with the help of the NMR spectroscopy method.

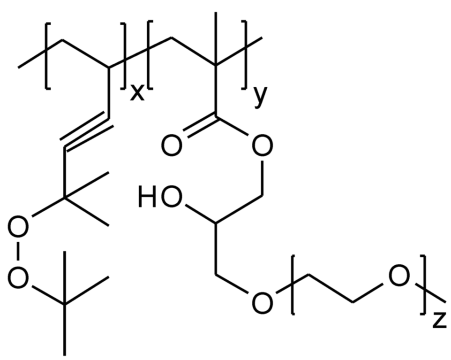

Fig. 1. Schematic structure of the poly(VEP-co-GMA)-graftPEG polymer 
After the purification, the copolymer poly(VEP-coGMA)-graft-PEG contained VEP-GMA-PEG functional links (1.2:50.2:48.6 mol\%). The molecular weight of the polymer was measured using the sizeexclusion chromatography (SEC) method on a Waters $150 \mathrm{C}$ chromatograph equipped with a built-in refractometric detector (Waters Corporation, USA) and a Shodex 602 column (Kawasaki, Japan). The flow rate acquired values of 0.5 and $2.5 \mathrm{~cm}^{3} / \mathrm{min}$. The values determined for the molecular weight parameters of poly(VEP-co-GMA)-graft-PEG are $M_{n}=$ $=90 \mathrm{kDa}, M_{w}=165 \mathrm{kDa}$, and $D=M_{w} / M_{n}=1.83$.

Aqueous dispersions of the polymer poly(VEP-coGMA)-graft-PEG and its complexes with drugs (Dox and Les-3833) were prepared according to the following procedure $[7,14]$. Firstly, the polymer and the drug were dissolved in DMSO, and then the solutions were transferred into water. For this purpose, $45 \mathrm{mg}$ of the polymer were dissolved in $0.15 \mathrm{ml}$ of DMSO, and the corresponding drug quantity (1.5$7.0 \mathrm{mg}$ ) was dissolved in $0.10 \mathrm{ml}$ of DMSO. The polymer and drug solutions were mixed together, added to $4.25 \mathrm{ml}$ of saline (the $0.9 \%$ solution of $\mathrm{NaCl}$ in water), and subjected to the ultrasonic dispersion for $10 \mathrm{~s}$. Unbound doxorubicin was removed with the help of cellulose dialysis membranes (Sigma-Aldrich), which could retain polymers with molecular weights exceeding $3.5 \mathrm{kDa}$.

We also prepared a reference solution of the polymer carrier without a drug. For this purpose, $45 \mathrm{mg}$ of polymer were dissolved in $0.15 \mathrm{ml}$ of DMSO. Then this solution was added to $4.25 \mathrm{ml}$ of saline and subjected to the ultrasonic dispersion for $10 \mathrm{~s}$.

\subsection{Research methods}

The morphology of micelles formed by polymer molecules, as well as that of polymer-drug complexes, was studied using the small-angle X-ray scattering (SAXS) method. The SAXS curves were measured at the P12 BioSAXS station of the European Molecular Biology Laboratory (EMBL) at the PETRA III storage ring of the German Synchrotron Research Centre (DESY, Hamburg, Germany) with the help of a Pilatus 2M detector (1475-1679 pixels, Dectris, Switzerland) and the synchrotron radiation at the wavelength $\lambda=1 \AA$. The distance between the specimen and a detector was $4 \mathrm{~m}$, which allowed the measurements to be performed within the $q$-interval of the scattering vector from 0.6 to $4 \mathrm{~nm}^{-1}$. The $q$-range was calibrated using the standard diffraction pattern of silver behenate $\left(\mathrm{C}_{22} \mathrm{H}_{43} \mathrm{O}_{2} \mathrm{Ag}\right)$. The experimental data were normalized with regard for the background scattering in the aqueous buffer solution. The measurements were registered every $0.05 \mathrm{~s}$. To be sure that there were no deviations provoked by radiationinduced damages, all registered scattering curves were compared with the reference measurement (as a rule, it was the first exposure) and afterward processed with the help of an automated program using the method described in work [24].

The sizes and shapes of micelles were examined on a transmission electron microscope JEM-200A (JEOL, Japan) at an accelerating voltage of $200 \mathrm{kV}$. Samples of colloidal solutions were prepared, as was described above. If necessary, they were diluted with doubledistilled water.

Samples were deposited on substrates by spraying the researched solution making use of an ultrasonic dispersant UZDN-1A (LLC Ukrrosprylad, Ukraine), which allowed us to obtain a homogeneous coating over the substrate surface. As substrates, thin amorphous carbon films deposited on copper grids were used. The average diameter $d_{\text {aver }}$ of the particles and their size distribution (the polydispersity index, PDI) were calculated by statistically processing at least 500 particles using the software program Atlas (Tescan, Czech Republic).

Hydrodynamic dimensions of polymer micelles and polymer-drug complexes were measured using the dynamic light scattering (DLS) method on a Zetasizer Nano ZS (Malvern Instruments GmbH, Germany) and a DynaPro NanoStar (Wyatt Technology, USA) instrument. Samples were prepared for DLS measurements, as was already described above. If necessary, they were diluted with double-distilled water, $\mathrm{pH}=6.5 \div 7.0$. Three to five measurements were performed for every sample (each measurement included five cycles, with an interval of 5 min between the measurements).

The zeta potential was measured on a Zetasizer Nano ZS instrument at a fixed temperature of $25{ }^{\circ} \mathrm{C}$. Six measurements were performed for every sample. The results obtained for the zeta potential were reproduced with an accuracy of $5 \%$. Aqueous dispersions with a polymer concentration of $10 \mathrm{mg} / \mathrm{ml}$ were used for the DLS and TEM studies.

The absorption spectra of the polymer and its complex with the drug in the UV and visible spectral

ISSN 2071-0194. Ukr. J. Phys. 2020. Vol. 65, No. 8 
intervals were registered on a Nanodrop ND-1000 device (Thermo Scientific, USA).

The photoluminescence spectra were registered on an automated spectrometer. Photoluminescence was excited by light with a wavelength of $260 \mathrm{~nm}$. The emitted radiation was selected with the help of a primary monochromator MDR-2 (LOMO, Russia).

\section{Results and Their Discussion}

\subsection{Research of micellar complexes of the comb-like PEG-containing polymer and the water-soluble antibiotic doxorubicin (Dox)}

As one can see from the SAXS diffraction patterns of poly(VEP-co-GMA)-graft-PEG and the poly(VEPco-GMA)-graft-PEG ... Dox complex (Fig. 2), the upper and lower limits of the wave-vector interval, where the dependence of scattering intensity on the scattering vector is a linear function in the log-log coordinates, show the region size, where the object is a fractal. The slope $\alpha$ of the linear section depends on the internal structure of micelles. Taking the examined polymer concentration $(0.01 \mathrm{~g} / \mathrm{ml})$ into account, we may assume that this value corresponds to the upper limit of the dilute solution, and the values obtained for the parameter $\alpha$ should be considered as "apparent", i.e., a certain influence of the interaction between particles may take place. But this assumption does not affect our conclusions concerning the doxorubicin adsorption, because it was relative changes of the parameter $\alpha$ - in the current case, the "apparent" parameter $\alpha$ - that were analyzed, when loading doxorubicin.

The $\alpha$-values calculated for poly(VEP-co-GMA)graft-PEG(750) micelles and for micelles of the complexes of this polymer and Dox taken in various ratios correspond to the structure of the bulk and surface fractals [25]. For the pure polymer and at low Dox concentrations, $\alpha<3$, which is typical of a bulk fractal with a loose particle packing. This case is characterized by the following relation between the volume $V$ and the linear size $l$ of the fractal:

$V \sim l^{\alpha}$

When the Dox concentration exceeded $4 \%$, the $\alpha$ parameter grew within the interval from 3 to 4 . This case corresponds to the surface fractal, a particle with

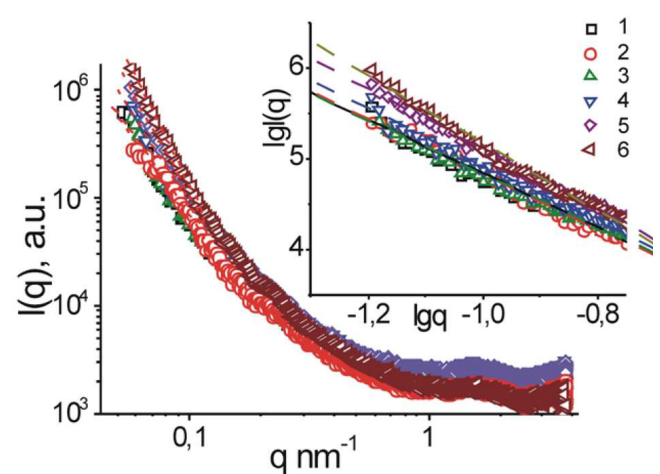

Fig. 2. SAXS diffraction patterns of the poly(VEP-co-GMA)graft-PEG (1) and poly(VEP-co-GMA)-graft-PEG ... Dox solutions $(2-6)$. The polymer concentration is $10 \mathrm{mg} / \mathrm{ml}$. The Dox concentration is 0.3 (2), 0.4 (3), 0.5 (4), 0.6 (5), and $1.4 \mathrm{mg} / \mathrm{ml}(6)$. The linear (in the log-log coordinates) sections of diffraction patterns are shown in the inset. Solid lines illustrate linear approximations according to the scaling concept

a dense nucleus and a fractal surface area $S$ satisfying the relation

$S \sim l^{6-\alpha}$.

According to the DLS and TEM data (see Table 1 and Fig. 3), an appreciable decrease in the sizes of Dox-containing micelles with respect to those of Doxfree ones was observed. These results also confirm the higher compactness of micellar structures in which the amount of Dox molecules bound into the complex with the polymer is larger.

The formation of chemical bonds between Dox and polymer molecules in the micelles is evidenced by the study of their $\zeta$-potentials. The PEG-containing copolymer has a negative potential varying from -0.2 to $-0.3 \mathrm{mV}$, and the free Dox - a positive potential of $+3.8 \mathrm{mV}$. At the same time, their Dox-containing complexes have a total positive potential, which increases together with the Dox content in the micelle. Since Dox that was used to produce the drug is the hydrochloride of an amine-containing molecule, it is evident that it dissociates in an aqueous solution to form either positively charged Dox molecules (each with an amino group) or their associates consisting of a few Dox molecules that interact either with the negatively charged molecule of the PEG-containing polymer or, more likely, with a micellar structure composed of its several molecules in the solution. The adduct of the polymer interaction with Dox acquires a total positive potential and equals $+1.6 \mathrm{mV}$, which 


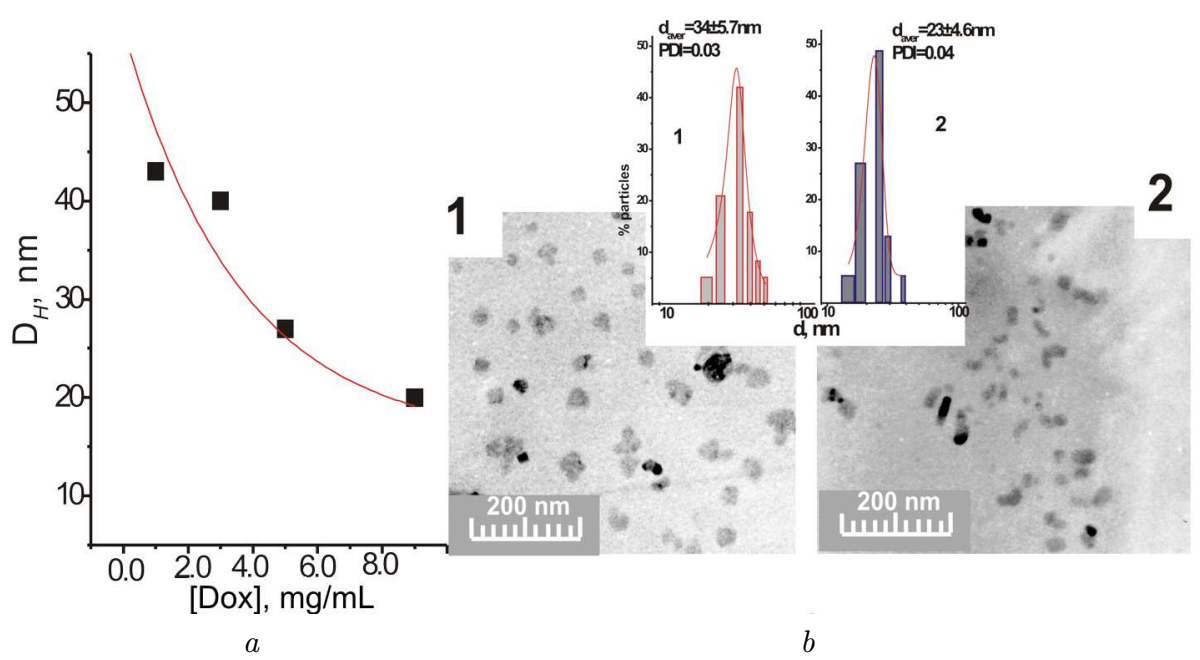

Fig. 3. Dependence of the hydrodynamic size of polymer micelles on the Dox concentration (a) and the corresponding TEM images of polymer micelles (b1) and their complexes with Dox $(0.3 \mathrm{mg} / \mathrm{ml})(b 2)(b)$. The corresponding histograms for the micelle size distributions are shown in the inset. The poly(VEP-co-GMA)-graft-PEG concentration is $10 \mathrm{mg} / \mathrm{ml}, \mathrm{pH}=6.7$

Table 1. Parameters of micelles formed by the polymer carrier poly(VEP-co-GMA)-graft-PEG and its micellar complexes with doxorubicin

\begin{tabular}{|l|c|c|c|}
\hline \multicolumn{1}{|c|}{ Polymer } & $\begin{array}{c}\text { Average } \\
\text { hydrodynamic }\end{array}$ & $\begin{array}{c}\text { Average } \\
\text { diameter }^{a}(\mathrm{~nm})\end{array}$ & $\begin{array}{c}\zeta \text {-potential } \\
(\mathrm{mV})\end{array}$ \\
\hline $\begin{array}{l}\text { Poly(VEPeter } \\
\text { (nm) }(\mathrm{nm})\end{array}$ & $34.0 \pm 5.7$ & -0.25 \\
$\begin{array}{l}\text { Complex of Dox with poly(VEP-co-GMA)- } \\
\text { graft-PEG(750) }\end{array}$ & 59.0 & $23.4 \pm 4.6$ & $+1.6 \ldots+3.1$ \\
\hline
\end{tabular}

${ }^{a}$ According to DLS data; ${ }^{b}$ according to TEM data.

confirms the binding of Dox molecules with a micelle formed by several molecules of the comb-like polymer owing to their electrostatic interaction. An increase of the electrical conductivity of the polymer solution, when the Dox solution is added, occurs (Fig. 4, a) due to the expulsion of hydroxynium cations into the solution, which takes place at the formation of the complex of the polymeric carrier with Dox and testifies to the favor of the proposed mechanism. Note that the addition of a Dox solution to distilled water insignificantly affects the conductivity growth.

The presence of bound Dox in the aqueous system is evidenced by electronic spectra measured in the ultraviolet and visible spectral intervals for the systems that contained Dox ... carrier complexes (Fig. 4, b). Furthermore, the shift of the absorption band of bound Dox at $230 \mathrm{~nm}$ (Fig. 4, b, curve 4) into the bathochromic region can probably be explained by the formation of its complexes with poly(VEPco-GMA)-graft-PEG. In the excitation and luminescence spectra of aqueous Dox solutions and the products of the interaction of Dox with a polymeric carrier (Fig. $4, b$ ), one can see that their main peaks coincide. The presented data demonstrate that only Dox reveals luminescence properties in the examined spectral interval. However, a substantial increase in the Dox luminescence intensity is observed owing to the Dox binding to the polymer. In our opinion, this occurs because water has an ability to "quench" luminescence, and the polymeric carrier "protects" the drug from its contact with the aqueous medium, thus eliminating the luminescence "quenching". All those facts 


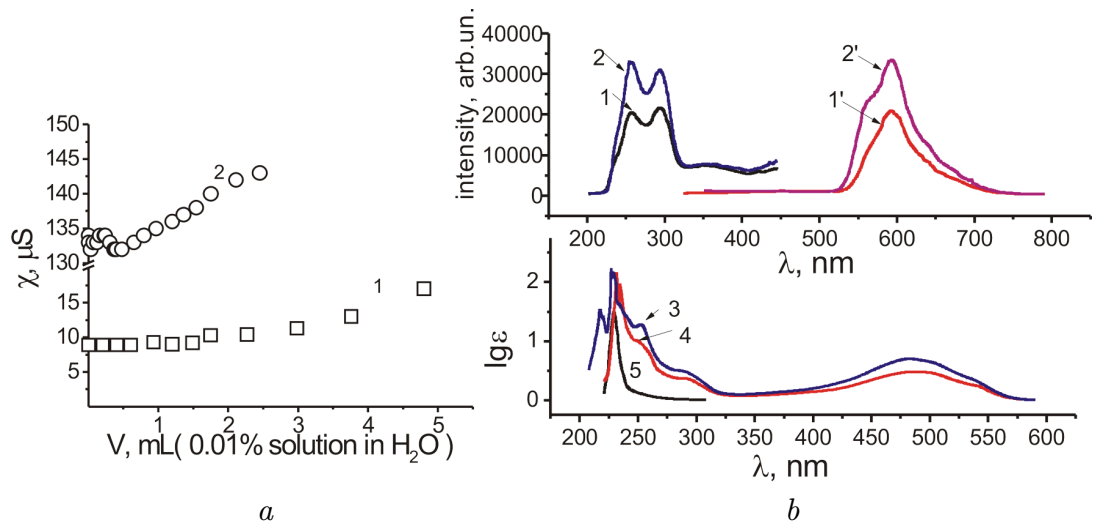

Fig. 4. Dependences of the electrical conductivity of water (1) and the aqueous solution of polymer (2) on the amount of Dox (a). Excitation $(1,2)$ and luminescence $\left(1^{\prime}, 2^{\prime}\right)$ spectra of the aqueous solutions of free and carrier-bound Dox, and the electronic spectra of the aqueous solutions of free Dox (3), Dox complex with poly(VEP-co-GMA)-graft-PEG (4), and poly(VEP-co-GMA)graft-PEG (5) (b)

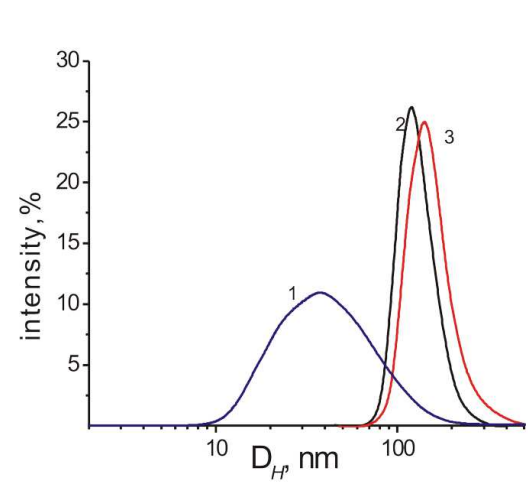

$a$

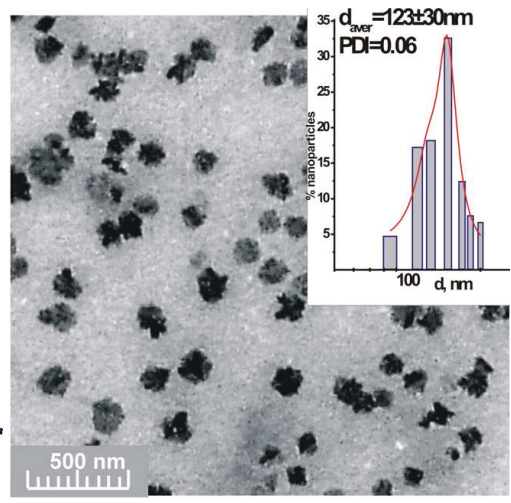

$b$

Fig. 5. Sizes of micelles with the complexes poly(VEP-co-GMA)-graft-PEG and Dox (1) and Les-3883 (2,3). The polymer concentration is $10 \mathrm{mg} / \mathrm{ml}(1)(a)$. The Les-3883 concentration is 0.4 (2) and $0.8 \mathrm{mg} / \mathrm{ml}$ (3). TEM image of Les-3883 particles with poly(VEP-co-GMA)-graft-PEG (b). The histogram for the particle size distribution is shown in the inset

give evidence to the formation of isolated hydrophobic zones containing bound Dox. Their existence agrees with the results of the SAXS study concerning the colloid-chemical parameters of the complexes.

\subsection{Research of micellar complexes of the PEG-containing comb-like polymer and the hydrophobic derivatives of thiozalidinone (Les-3883)}

In comparison with the sizes of the micelles formed by the PEG-containing comb-like polymeric carrier, either alone or in combination with the water-soluble antitumor antibiotic Dox, and as follows from the results of DLS and TEM experiments (see Fig. 5), the sizes of the structures formed by the new waterinsoluble antitumor drug Les-3883 with the polymeric carrier are larger (100-140 nm) and weakly depend on the thiozalidinone content.

The SAXS diffraction patterns in Fig. 6 demonstrate that the structures formed by Les-3883 with the polymer are characterized by a denser filling, as is evidenced by a substantial growth of the parameter $\alpha$, whose value becomes close to 4 . This fact confirms the formation of continuous dense particles with a smooth surface. The morphology of the structures created in water by the water-insoluble substance Les-3883 with the polymeric carrier weakly depends on the Les3883 content in the supramolecular structure. These results allow us to propose the following formation 


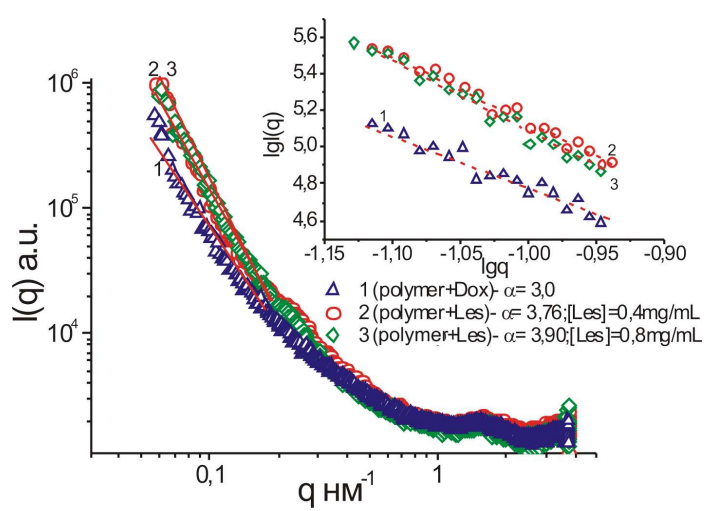

Fig. 6. SAXS diffraction patterns of the micellar complexes poly(VEP-co-GMA)-graft-PEG and Dox (1) and the Les-3883 particles (2,3). The polymer concentration is $10 \mathrm{mg} / \mathrm{ml}$. The Dox concentration is $0.3 \mathrm{mg} / \mathrm{ml}(1)$. The Les-3883 concentration is 0.4 (2) and $0.8 \mathrm{mg} / \mathrm{ml}(3)$. The linear (in the log-log coordinates) sections of diffraction patterns are shown in the inset. Solid lines illustrate linear approximations according to the scaling concept

mechanism for Les-3883 particles. Namely, they are a result of the nucleation in the presence of micelles of the polymer surfactant. The latter plays the role of a soft template nanoreactor responsible for the formation of particles characterized by approximately the same shapes and sizes and covered with an adsorption shell composed of polymer molecules.

\section{Conclusions}

A substantial interaction is observed between the PEG polymer and the water-soluble drug doxorubicin. The Dox molecules are adsorbed in the cores of polymer micelles, which results in a more compact packing of the inner part of micelles. This scenario is in agreement with the data of SAXS and photoluminescence studies. The main driving force of this interaction is electrostatics, because the polymer is negatively charged and the drug has a positive charge. The increase of the free ions concentration in the course of this interaction brings about the growth of the system entropy and enhances the formation of polymerDox complexes. In the case of the hydrophobic drug Les-3883, the interaction of the latter with the polymer is much weaker, the structure of densely packed drug particles is almost independent of their concentration in the solution, and the size of those particles is much larger than the size of polymer micelles. This is explained by the sedimentation-nucleation mecha- nism of formation and stabilization of the particles of water-insoluble substance in the aqueous system, when the micelles of the PEG-containing surfactant polymer play the role of nanoreactors that nucleate the particles and create a stabilizing hydrophilic shell on their surface.

The authors are thankful to Prof. A.S. Voloshinovskyi and Prof. V.V. Vistovskyi (Ivan Franko National University of Lviv) for their assistance in studying the luminescence properties of polymer complexes and the Senior researcher V.O. Glazunova (DonPTI of the $N A S$ of Ukraine) for the TEM research of polymer complexes.

1. L. Falzone, S. Salomone, M. Libra. Evolution of cancer pharmacological treatments at the turn of the third millennium. Front. Pharmacol. 9, 1300 (2018).

2. B. Mansoori, A. Mohammadi, S. Davudian et al. The different mechanisms of cancer drug resistance: A brief review. Adv. Pharm. Bull. 7, 339 (2017).

3. J. Dey, R. Ghosh, R. Das Mahapatra. Self-assembly of unconventional low-molecular-mass amphiphiles containing a PEG chain. Langmuir 35, 846 (2018).

4. Y. Kang, K. Liu, X. Zhang. Supra-amphiphiles: A new bridge between colloidal science and supramolecular chemistry. Langmuir 30, 5989 (2014).

5. A. Riabtseva, L.I. Kaberov, L. Noirez et al. Structural characterization of nanoparticles formed by fluorinated poly (2-oxazoline)-based polyphiles. Eur. Polymer. J. 99, 518 (2018).

6. M.F. Maitz. Applications of synthetic polymers in clinical medicine. Biosurf. Biotribol. 1, 161 (2015).

7. A. Riabtseva, N. Mitina, I. Grytsyna et al. Functional micelles formed by branched polymeric surfactants: Synthesis, characteristics, and application as nanoreactors and carriers. Eur. Polym. J. 75, 406 (2016).

8. S. Imai, M. Takenaka, M. Sawamoto et al. Self-sorting of amphiphilic copolymers for self-assembled materials in water: polymers can recognize themselves. J. Am. Chem. Soc. 141, 511 (2018).

9. S.S. Kulthe, Y.M. Choudhari, N.N. Inamdar et al. Polymeric micelles: authoritative aspects for drug delivery. Des. Monomer. Polymer. 15, 465 (2012).

10. Y. Zhang, Y. Huang, S. Li. Polymeric micelles: nanocarriers for cancer-targeted drug delivery. AAPS Pharmscitech. 15, 862 (2014).

11. A. Riabtseva, N. Mitina, N. Boiko et al. Structural and colloidal-chemical characteristics of nanosized drug delivery systems based on pegylated comb-like carriers. Chem. Chem. Technol. 6, 291 (2012).

12. R. Murali, P. Vidhya, P. Thanikaivelan. Thermoresponsive magnetic nanoparticle-aminated guar gum hydrogel 
system for sustained release of doxorubicin hydrochloride. Carbohydr. Polymer. 110, 440 (2014).

13. L. Kobylinska, N. Boiko, R. Panchuk et al. Putative anticancer potential of novel 4-thiazolidinone derivatives: cytotoxicity towards rat C6 glioma in vitro and correlation of general toxicity with balance of free radical oxidation in rats. Carbohydr. Polymer. J. 57, 151 (2016).

14. L. Kobylinska, I. Ivasechko, N. Skorokhyd et al. Enhanced proapoptotic effects of water dispersed complexes of 4-thiazolidinone-based chemotherapeutics with a pegcontaining polymeric nanocarrier. Nanoscale Res. Lett. 14, 144 (2019).

15. L. Kobylinska, I. Patereha, N. Finiuk et al. Comb-like PEG-containing polymeric composition as low toxic drug nanocarrier. Cancer Nanotechnol. 9, 1 (2018).

16. V.I. Petrenko, M.V. Avdeev, L. Almasy et al. Interaction of mono-carboxylic acids in benzene studied by small-angle neutron scattering. Colloids Surf. A 337, 91 (2009).

17. M.V. Avdeev, V.L. Aksenov, O.V. Tomchuk et al. The spatial diamond-graphite transition in detonation nanodiamond as revealed by small-angle neutron scattering. J. Phys. Condens. Matter 25, 445001 (2013).

18. O.V. Tomchuk, L.A. Bulavin, V.L. Aksenov et al. Smallangle scattering from polydisperse particles with diffusive surface. J. Appl. Crystallogr. 47, 642 (2014).

19. L. Melnikova, V.I. Petrenko, M.V. Avdeev et al. Effect of iron oxide loading on magnetoferritin structure in solution as revealed by SAXS and SANS. Colloids Surf. B 123, 82 (2014).

20. S.A. Voronov, E.M. Kiselyov, S.S. Minko et al. Structure and reactivity of peroxide monomers. J. Polym. Sci. Pol. Chem. 34, 2507 (1996).

21. D. Havrylyuk,. B. Zimenkovsky, O. Vasylenko et al. Synthesis of new 4-thiazolidinone-, pyrazoline-, and isatinbased conjugates with promising antitumor activity. J. Med. Chem. 55, 8630 (2012).

22. Al. Steyermark. Quantitative Organic Microanalysis (Academic Press, 1961) [ISBN: 9780323161367].
23. N.D. Cheronis, T.S. Ma. Organic Functional Group Analysis by Micro and Semimicro Methods (Interscience, 1964).

24. D. Franke, A.G. Kikhney, D.I. Svergun et al. Automated acquisition and analysis of small angle X-ray scattering data. Nucl. Instrum Methods A 689, 52 (2012).

25. P.W Schmidt. Use of scattering to determine the fractal dimension. In The Fractal Approach to Heterogeneous Chemistry. Edited by D. Avnir (Wiley, 1989), p. 67.

Received 28.03.20.

Translated from Ukrainian by O.I. Voitenko

Н.Є. Мітіна, А.О. Рябцева,

В.М. Гарамус, Р.Б. Лесик, К.А. Волянюк,

О.М. Іжик, О.С. Заіченко

МОРФОЛОГІЯ МІЦЕЛ

ГРЕБЕНЕПОДІБНОГО ПЕГ-ВМІСНОГО

КОПОЛІМЕРУ 3 ПРОТИПУХЛИННИМИ

РЕЧОВИНАМИ З РІЗНОЮ РОЗЧИННІСТЮ У ВОДІ

$\mathrm{P}$ е $з$ ю м е

Контрольована доставка протипухлинних ліків базується на їх взаємодії з молекулами-носіями. Амфіфільні полімери, завдяки формуванню складних міцелярних нанокомплексів, дають змогу завантажити різноманітні ліки. Взаємодія гребінчастого ПЕГ-вмісного полімеру (полі(ВЕП-коГМА)-графm-ПЕГ) з водорозчинним протипухлинним антибіотиком доксорубіцин і водонерозчинними новими похідними тіозалідінону Les 3883 з високою протипухлинною дією досліджувалась у водних розчинах за допомогою малокутового рентгенівського розсіювання, динамічного розсіювання світла, електронної мікроскопії та люмінесценції. Було спостережено формування і структурні зміни полімерних міцел та їх комплексів з лікарськими препаратами. Аналіз даних вказує на відмінний характер в організації супрамолекулярних комплексів в залежності від водорозчинності лікарських препаратів. Підтверджено потенційні властивості полі(ВЕП-ко-ГМА)-графт-ПЕГ для подовження циркуляції ліків. 